\title{
Simplification of the Intravenous Glucose Tolerance Test (ivGTT) in Rats
}

\author{
Junji MIZOGUCHI, Shigeo YAMADA, Tsuneo OHTAKI \\ and Tomonori IMAMICHI* \\ Hatano Research Institute Food and Drug Safety Center, 729-5 Ochiai, \\ Hadano-shi, Kanagawa-ken 257, Japan, and *Department of \\ Physiology, Nippon Veterinary and Zootechnical \\ College, Musashino-shi, Tokyo 180.
}

(Received 19 March 1985 / Accepted 21 June 1985)

\begin{abstract}
A simplified technique was established for the intravenous glucose tolerance test (ivGTT) in unanesthetized rats. In order to evaluate the relation between insulin secretion, glucose load and glucose disappearance rate, precatheterized rats were given glucose ranging in dose from 0.25 to $2.0 \mathrm{~g} / \mathrm{kg}$ bw by intravenous injection. A highly linear correlation was observed in glucose disappearance rate during a period of $4-32 \mathrm{~min}$. A glucose load greater than $0.5 \mathrm{~g} / \mathrm{kg}$ bw induced a maximum response in insulin secretion. Small blood samples were collected using the orbital bleeding technique at 4,16 and 28 minutes after a glucose load of $1.0 \mathrm{~g} / \mathrm{kg}$ bw had been given and then $\mathrm{T} 1 / 2$, the time taken for the glucose level to fall by one half, was calculated. The mean T1/2 was significantly longer in alloxan-or cyproheptadin-diabetic rats than that in the intacts. These data indicate that a glucose load of $1.0 \mathrm{~g} / \mathrm{kg}$ administered by intravenous injection with the T $1 / 2$ calculated between 4 and 32 minutes would provide an accurate means of assessing pancreatic endocrine function.
\end{abstract}

\section{ブドウ糖の静脈内投与による簡便なラット耐糖能試験法}

溝口順二・山田茂夫・大滝恒夫

$$
\text { 今道友則* }
$$

（財）食品薬品安全センター秦野研究所

*日本獣医畜産大学生理学教室

\footnotetext{
サイプロヘプタジン $[14]$, ストレプトゾトシン $[3]$, フロリジン[12]などの大量投与では, 膵ランゲルハンス 氏島 B 細胞 (以下, ラ氏島) に障害を与えることが知られ ており, 薬物の毒性試験においても膵内分泌機能検査が 必要とされることが多い。

ラ氏島が障害を受けた時にはインスリンの分泌不足に
}

よる糖代謝の異常が主な症状となるため，その診断に際 しては糖負荷試験が最も簡単で有用な検査法とされてい る[4]。

糖負荷試験は一定量の糖質を負荷した後の過血糖の程 度やその後の血糖值の推移から膆ラ氏島の障害の有無を 判定する方法である。糖の負荷方法には経口法と非経口 
法とがあるが，ヒトでは主にブドウ糖を経口的に投与す る方法が用いられ，ラットなどの実験動物においても経 口投与法が繁用されている[4,8]。経口投与法は投与が 容易である反面, 検查に長時間を要することや, 消化管 からの糖吸収能の影響を受けるなどの不利な点もある。

薬物の毒性試験の一環として蔵器機能検査を実施する 場合には，反応が鋭敏で特異性が高いこと，動物に対す る負荷が軽いことの他に大量の動物を短時間で検査でき ることなどが要求される。本報では, ブドウ糖の単回静 脈内投与後の血糖値の半減時間から脺ラ氏島の障害の有 無を判定する簡便なラット糖負荷試験法について検討し た。

実験には日本チャールズリバーから購入した 8 週龄の S D系雄ラットを用いた。血糖值はグルコース B-テス ト・ワコー（和光純薬工業）を用いて酵素法により，血

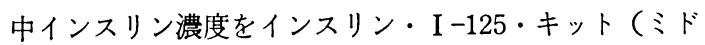
リ十字）を用いたラジオイムノアッセイにより測定し た。血糖值およびインスリン濃度の日内変動の影響をさ けるため, 実験を全て11時から15時の間におこなった。 各実験群にはそれぞれ 6 ないし11匹のラットをあてた。 結果は平均と標準誤差で表わし, Student's t-テスト により $5 \%$ を有意水準とした。

まず正常ラットでのグルコース投与後の血糖值の経時 的変化およびグルコース投与量とインスリン分泌量の関 係について調べた。実験には以下に示したWeeks の方 法[13]でカニューレを装着したラットを用いた。実験の 前日に，エール麻酔下で右鼠径部を切開し大腿動脈を露 出した。神経, 結合組織を剝離した後, 血管壁に小切開を 加えポリエチレンチューブ ( P E 10, 20, Clay Adams;
USA）で自作したカニューレを先端が腹大動脈に達す るまで約 $6 \mathrm{~cm}$ 插入し結さつ固定した。力ニューレの他 端を鼠径部の切開口から皮下に通し頸部から体表に露出 させて固定した。実験に供するまでカューレの内部をへ パリン加生理食塩水で満たし，端を閉じた。手術には約 4 分間を要した。翌日，これらの動物に無麻酔下で尾静 脈よりグルコース（Dグルコース，メルク） $50 \%(\mathrm{w} / \mathrm{v})$ 溶液を投与した。グルコースの投与量は体重 $1 \mathrm{~kg}$ 当り $0.25 \mathrm{~g}$ ( 1 群)，0.50g ( 2 群)，1.00g ( 3 群)，2.00g ( 4 群)とした。投与後， $0,2,4,8,12,16,20,28,32$, $36,56,88$ 分目にヘパリン処理した注射筒を用い, カ二 ューレを通して $120 \mu 1$ ずつ採血し， $0^{\circ} \mathrm{C}$ 下で 6,000 回転 で10分間遠心分離して, 得られた血漿中の血糖とインス リン值を測定した。

グルコースの投与により血糖は急激に上昇し，いずれ の投与群に打いても2 分目に最高濃度に達した（1 群 $229.2 \pm 8.9 ， 2$ 群 $361.3 \pm 10.9 ， 3$ 群 $520.5 \pm 19.1 ， 4$ 群 $763.5 \pm 28.4 \mathrm{mg} / \mathrm{dl}$ )。その後は減少に転じたが 2 相 性の減少経過をたどった。第 1 相は 2 分から 36 分までの 急激に減少する部分で，第 2 相はそれに続く88分までの 緩慢に減少する部分である。血糖值は第 1 の減少相をへ

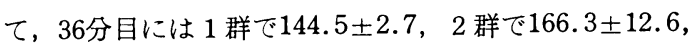
3 群で $203.0 \pm 17.5,4$ 群で $208.4 \pm 28.3 \mathrm{mg} / \mathrm{dl}$ まで減 少したがここの減少相では血糖の減少率と時間経過に直 線関係が珰められた。そこで最少二乗法により 4 分から 32分までの血糖值の減少式を求めたところ, どの群の減

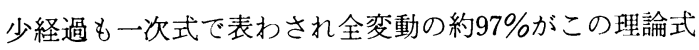
で説明された。Table $1 \mathrm{~A} に$ に $1.0 \mathrm{mg} / \mathrm{kg}$ 投与群の減 少式を示した。この減少式から血糖値が半分になる時間

Table 1. Blood glucose regression line and $\mathrm{T} 1 / 2$ calculated by the method of least squares after a $1.0 \mathrm{~g} / \mathrm{kg} \mathrm{bw}$ glucose load

(A) Multiple sampling by A. abdominal catheterization.

\begin{tabular}{ccccc}
\hline No. & $\mathrm{Y}=$ & $\mathrm{aX}+\mathrm{b}$ & $\mathrm{r}$ & $\mathrm{T} 1 / 2(\mathrm{~min})$ \\
\hline 1 & $\mathrm{Y}=-10.5 \mathrm{X}+555$ & -0.99 & 24.5 \\
2 & $\mathrm{Y}=-11.6 \mathrm{X}+533$ & -0.99 & 21.0 \\
3 & $\mathrm{Y}=-9.7 \mathrm{X}+484$ & -0.99 & 24.3 \\
4 & $\mathrm{Y}=-8.3 \mathrm{X}+465$ & -0.99 & 27.6 \\
5 & $\mathrm{Y}=-6.0 \mathrm{X}+454$ & -0.99 & 36.1 \\
6 & $\mathrm{Y}=-7.1 \mathrm{X}+472$ & -0.98 & 31.1 \\
\cline { 1 - 1 } & Mean \pm S. E. of T $1 / 2$ & $27.4 \pm 2.2$ \\
\hline
\end{tabular}

Values were calculated between 4 and $32 \mathrm{~min}$. 
(B) Triple samling by orbital vein puncture.

\begin{tabular}{|c|c|c|c|}
\hline No. & $a X+b$ & $\mathbf{r}$ & $\mathrm{T} 1 / 2(\mathrm{~min})$ \\
\hline 1 & $Y=-13.1 X+555$ & -0.99 & 19.2 \\
\hline 2 & $Y=-12.2 X+524$ & -0.99 & 19.5 \\
\hline 3 & $Y=-11.3 X+536$ & -0.99 & 21.8 \\
\hline 4 & $Y=-10.7 X+506$ & -0.99 & 21.6 \\
\hline 5 & $\mathrm{Y}=-9.5 \mathrm{X}+555$ & -0.99 & 27.2 \\
\hline 6 & $Y=-8.4 X+448$ & -0.99 & 24.8 \\
\hline 7 & $Y=-8.0 X+515$ & -0.99 & 30.4 \\
\hline 8 & $Y=-9.5 X+522$ & -0.96 & 25.6 \\
\hline 9 & $Y=-11.7 X+485$ & -0.94 & 18.7 \\
\hline 10 & $Y=-6.9 X+555$ & -0.94 & 38.1 \\
\hline 11 & $Y=-6.2 X+480$ & -0.94 & 36.7 \\
\hline \multicolumn{3}{|c|}{ Mean \pm S. E. of $T 1 / 2$} & $8 \pm 2.0$ \\
\hline
\end{tabular}

Values were calculated for 4,16 and $28 \mathrm{~min}$.

（T1/2）を求めたところ 1 群 $42.3 \pm 2.1$ 分, 2 群 $28.8 \pm$ 0.7 分, 3 群 $27.4 \pm 2.2$ 分, 4 群 $21.5 \pm 1.5$ 分であった。 血中インスリン濃度は血糖の上昇に伴なって急激に增 加し 2 分目には最高濃度に達したが，インスリン濃度の 有意な増加 $(\mathrm{p}<0.05)$ は血糖が急激に減少した第 19 減少相に相当する時期に打いてのみみられ，グルコース 投与後36分目にはほぼ投与前の濃度に戾った。グルコー スを $0.5 \mathrm{~g} / \mathrm{kg}$ 以上投与した群でのインスリンの最高濃 度および36分間の総放出量に有意差はなかった。

つぎにカニューレにより腹大動脈から頻回に採血した 場合と, 眼窩静脈叢から 3 回のみ採血した場合について 半減時間を比較した (Table 1 B )。後者においてはグ ルコース $1.0 \mathrm{~g} / \mathrm{kg}$ を投与した後 $4,16,28$ 分目に外径 1.6 $\mathrm{mm}$ のガラス毛細管を用いて Riley の方法[9]により無 麻酔下で眼窩静脈叢から採血した。この場合の血糖值の 減少経過も，カニューレにより頻回に採血した場合と同 様に一次式で表わされ，またそれから求めた半減時間も $25.8 \pm 2.0$ 分とカニューレにより頻回に採血して求めた 場合の $27.4 \pm 2.2$ 分と差がなかった。

そこでグルコース $1.0 \mathrm{~g} / \mathrm{kg}$ を静脈内投与した後 4 , 16，28分目に眼窩静脈叢から採血する方法により粹内分 泌機能の異常が検出できるか否かを調べた (Fig. 1)。 実験的膆内分泌機能障害ラットの作出にはサイプロヘプ タジン $10 \mathrm{mg} / \mathrm{kg}$ の 14 日間経口投与, あるいはアロキサ ン $40 \mathrm{mg} / \mathrm{kg}$ の単回静脈内投与によった。サイプロヘプ タジンは膵ラ氏島に空胞変性を[14], アロキサンは壊死 をおこすことが知られている $[5]$ 。粹内分泌機能障害群
での半隇時間は, サイロヘプタジン群で85.6 $6 \pm 10.9$ 分, アロキサン群では $192.2 \pm 60.0$ 分と正常群より有意に延 長した。各群のグルコース投与前のインスリン濃度には 差がなかったが, サイプロヘプタジン群, アロキサン群 ではグルコースを投与してもインスリン濃度はほとんど 上昇しなかった。

内分泌機能試験では本来目的とするホルモンを直接測 定すべきであるが，測定が困難であることなどからホル モンの 標的器官の 変化をパラメーターとする場合が多 い。血糖值がインスリンの動態を把握するための良いパ ラメーターであることは, 本実験に打いて観察されたよ うに，膵ラ氏島障害ラットではグルコース投与後の血 糖値の半隇時間が有意に延長したことからも明らかであ る。

投与されたグルコースは，粹ラ氏島の B 細胞を直接刺 激してインスリンの分泌を促す［2]。ラットでのグルコ 一スの単回静脈内投与では, $0.5 \mathrm{~g} / \mathrm{kg}$ 以上であればイ ンスリンの最大分泌反応を引き起すことが知られた。し かしインスリンの分泌は, 膵ラ氏島に対する血糖值のフ イードバック作用のみで調節されているのではなく, 胃 腸ホルモン [1]や自律神経[11]などの関与もおおきい。 このことはグルコースの経口投与では静脈内へ投与した 時よりもより多くのインスリン分泌を促すことでも明ら

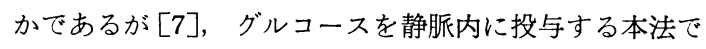
はこれらの影響をさけることができる。

ヒトでの静脈内投与による糖負荷試験にはLundback や Roger らの方法がある $[6,10]$ これはグルコース 
Intact
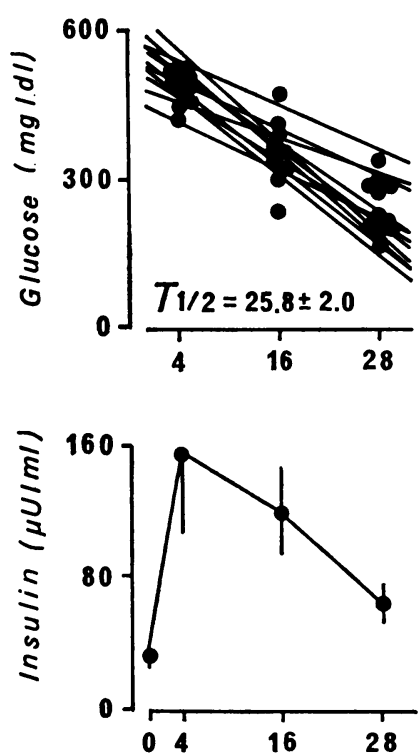

Cyproheptadin

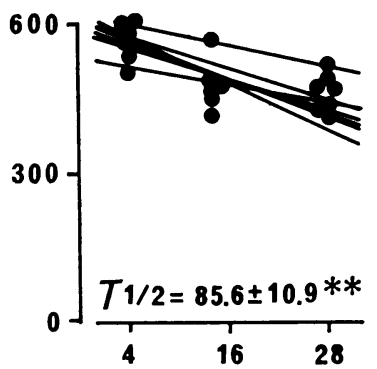

160

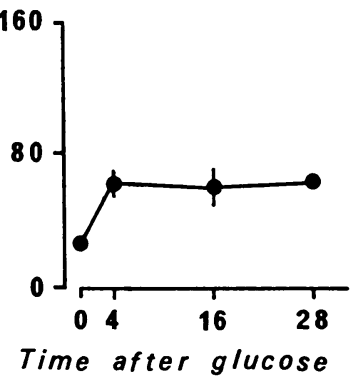

Alloxan
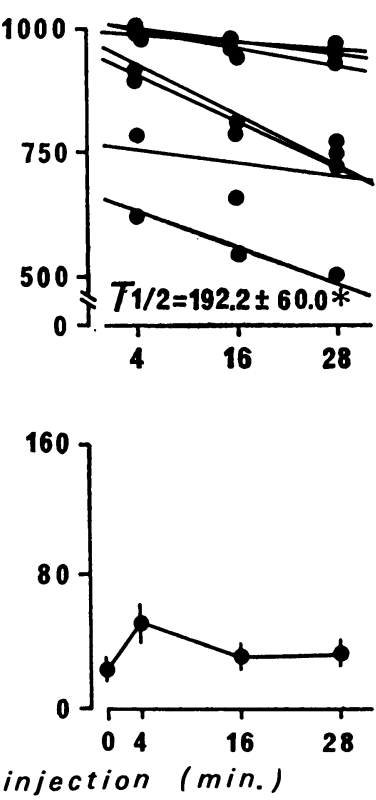

Fig. 1. Blood glucose regression lines and insulin secretory responses to glucose during $28 \mathrm{~min}$ after intravenous glucose load $(1.0 \mathrm{~g} / \mathrm{kg})$ in intact and in diabetic rats. Values are means $\pm \mathrm{S}$. E. of 7-11 determinations. $*: \mathrm{p}<0.05,{ }^{* *} \mathrm{p}<0.01$ compared with intacts.

$25 \mathrm{~g}$ を静脈内投与後, 経時的に採血し片対数グラフ上に 描かれる血糖值の減衰直線より減衰係数を求め比較する 方法であるが, 糖負荷後の血糖值は指数函数的下降経過 をとるため10分間隔で 6 回の採血が必要である $[6] 。 し$ かしラットに扒いては本実験で明らかなように，グルコ 一ス投与後 4 分から 32 分までの血糖值の減少経過は直線 式で表わされた。従ってこの間の任意な時間に 3 回採血 することにより容易に血糖の半減時間を算出できた。ま た動脈, 静脈いずれから採血しても半減時間に差はなか った。

静脈内投与による糖負荷試験の利点としては，短時間 で済むこと，消化管からの糖吸収能の影響がないことな どのほかに，糖同化能を係数化できることが挙げられて いる。今回の実験に扎いても，サイプロヘプタジン 1 $\mathrm{mg} / \mathrm{kg}$ 投与群での半減時間は $35.0 \pm 6.6$ 分であったが, 投与量を $10 \mathrm{mg} / \mathrm{kg}$ に增やすと半減時間も $85.6 \pm 10.9$ 分 に延長した。したがって本法に打いても脺ラ氏島の障害 を段階的に評価し得る可能性がある。通常われわれはグ ルコース $1.0 \mathrm{~g} / \mathrm{kg}$ を静脈内投与した後の 血糖の 半減時 間が正常ラットの平均土標準偏差 $\times 2$ 倍の範囲からはず
れたときには，その動物の䐏内分泌機能には異常がある と診断している。

（本論文の概要は, 第17回日本実験動物学会で発表し た。)

\section{要 約}

ブドウ糖をラットの静脈内に投与したあとの血糖の半 減時間（T 1/2）功判定する簡便な耐糖能試験法につ いて検討した。ブドウ糖投与後の血糖の変化を留置カ二 ューレ装着ラットをもちいて調べた。血糖は糖の投与後 2 分目に最高濃度に達したあと減少に転じたが， 4 分か ら32分までの減少経過は一次式で表わされた。インスリ ンの最大分泌反応のみられたブドウ糖 $1.0 \mathrm{~g} / \mathrm{kg}$ を投与 したあと $4,16,28$ 分目に眼窩静脈丵から採血し，得られ た血糖の減少式から 半減時間を求めたところ $25.8 \pm 2.0$ 分であった。この方法によりアロキサンおよびサイプロ ヘプタジン投与による実験的粹内分泌障害ラットの半減 時間を比較したところ，いずれも正常群より有意に延長 した。 


\section{文献}

[1] Brown, J. C., Dryburgh, J. R., Ross, S. A., and Dupre, J. (1975). Recent. Prog. Horm. Res. 31, 295-319.

[2 ] Donald, L. C., Leslie, L. B., and Gerold, M. G. (1968). Endocrinol., 83, 572-584.

[3] Junod, A., Lambert, A. E., Stauffacher, W., and Renold, A. E. (1969). J. Clin. Invest., 48, 21292139 .

[4] 葛谷信貞 (1970). 糖尿病, 13, 1-7.

[5] Lukens, F. D. W. (1948). Physiol. Rev., 28, 304330 .

[6] Lundback, K. (1962). Brit. Med. J., 2, 1507-1513.

[ 7] McIntyre, N., Holdsworth, C. D., and Turner, D.
S. (1965). J. Clin. Endoclinol. Metab., 25, 13171324.

[8] National Diabetes Data Group (NIH). (1979). Diabetes, 28, 1039.

[9] Riley, V. (1960). Proc. Soc. Exp. Biol. Med., 14, 751-754.

[10] Roger, L. L., and Daniel, P. Jr. (1971). J. Clin. Endocrinol., 33, 409-417.

[11] Steffens, A. B. (1975). Am. J. Physiol., 226, 17381744 .

[12] Wintero, R. W., Shultz, R. B., and Krehl, W. A. (1952). Endocrinol., 50, 388-398.

[13] Weeks, J. R., and Jows, J. A. (1960). Proc. Soc. Biol. Med., 104, 646-648.

[14] Wold, J. S., Longnecker, D. S., and Fischer, L. J. (1971). Tox. Appl. Pharmacol., 19, 188-201. 